UDC $544.65+661.43$

\author{
D. Girenko, O. Shmychkova, A. Velichenko
}

\title{
INFLUENCE OF Ti/Pt ELECTRODES HISTORY ON ITS ELECTROCHEMICAL PROPERTIES DURING ELECTROLYSIS OF NaCl
}

\author{
Ukrainian State University of Chemical Technology, Dnipro, Ukraine
}

\begin{abstract}
It was shown that the pre-reduced surface of the platinized titanium electrode undergoes a series of transformations during the anodic polarization. Oxygen-containing particles $\mathrm{OH}_{\text {ads }}$ are chemisorbed on the Ti/Pt surface in the low polarizations range. Such particles, depending on the $\mathrm{pH}$ of the near-electrode layer, can be in equilibrium with $\mathrm{OH}_{2}{ }^{+}$ads and $\mathrm{O}^{-}{ }_{\text {ads }}$. With increasing polarization, the formation of both atomic oxygen and phase oxide layers becomes possible. The formation of phase surface oxides occurs rapidly in supporting electrolytes, and the oxygen evolution proceeds on a completely oxidized surface. The presence of chloride ions in solution significantly decelerates this process. The higher the $\mathrm{Cl}^{-}$concentration, the longer the surface remains in the reduced state. The chloride ion acts as a depolarizer, discharging on the surface and interacting with surface oxygencontaining particles, thereby slowing down the oxidation of the surface. It was established that both direct oxidation of $\mathrm{Cl}^{-}$and its oxidation by labile oxygen-containing particles of the $\mathrm{OH}_{\mathrm{ads}}$ type occur on the reduced platinized surface. On the oxidized surface, the formation of hypochlorite occurs directly on the surface of the layer of platinum phase oxides with the participation of inert chemisorbed oxygen-containing particles and atomic oxygen. The desorption of the products of primary oxidation of $\mathrm{Cl}^{-}$becomes slower, and an increase in the degree of surface filling with active oxygen-containing particles of the $\mathrm{O}_{\text {ads }}$ type leads to a significant increase in the rate of chlorate formation.
\end{abstract}

Keywords: platinized titanium, electrode, pre-treatment, sodium hypochlorite, electrolysis.

DOI: $10.32434 / 0321-4095-2020-128-1-18-24$

\section{Introduction}

Platinized titanium is known to be the one of the most available dimensionally stable anodes. Such an electrode material has a number of unique operational and electrocatalytic properties [1]. The platinum coating can work at high anodic and cathodic polarizations and it has significant corrosion resistance in the presence of strong oxidizing agents.

The electrolysis of $\mathrm{NaCl}$ solutions over the entire concentration range usually proceeds on the oxidized surface of platinum [2]. In neutral solutions, three main processes are realized: (i) the oxidation of $\mathrm{Cl}^{-}$to hypochlorite, (ii) chlorite and chlorate, and (iii) oxygen evolution reaction. The current efficiency (CE) of hypochlorite reaches $85 \%$ on the reduced surface in concentrated $(1-2 \mathrm{M}) \mathrm{NaCl}$ solutions, and the process proceeds at lower polarizations of $0.4-0.45 \mathrm{~V}$. Under these conditions, chlorates are formed with an integrated current efficiency of less than 10\% [3]. However, the reduced surface gradually oxidizes during the electrolysis. At the same time, the number of active sites at which direct oxidation of $\mathrm{Cl}^{-}$is realized decreases. As a result, the $\mathrm{CE}$ of $\mathrm{ClO}^{-}$decreases to $70-75 \%$, and the current efficiency of chlorates almost doubles. On the oxidized surface, the direct oxidation of $\mathrm{Cl}^{-}$ even in 1-2 $\mathrm{M} \mathrm{NaCl}$ proceeds at the limiting current, the value of which is determined by the concentration of active centers on the electrode surface. The number of active centers decreases tenfold, as one can conclude after a comparison of the values of the limiting currents on the reduced and oxidized surfaces. This phenomenon was discussed in details in our previous publication [3]. However, it is not always advisable to electrolyze concentrated $\mathrm{NaCl}$ solutions in practice. The current efficiency of hypochlorite usually does not exceed $40 \%$ when low concentrated $\mathrm{NaCl}$ solutions (less than $0.2 \mathrm{M}$ ) are electrolyzed on platinum and platinized titanium. In addition, platinum exhibits a high catalytic activity 
in the oxidation of hypochlorite to chlorate with a current efficiency of more than $20 \%$ [4-6]. One of the ways to increase $\mathrm{CE}$ of $\mathrm{ClO}^{-}$and decrease $\mathrm{CE}$ of $\mathrm{ClO}_{3}{ }^{-}$is to prepare platinized titanium with a highly developed surface, since the decrease in the true current density does not significantly affect the $\mathrm{CE}$ of $\mathrm{ClO}^{-}$[7]. At the same time, the data on the kinetics of hypochlorite formation on platinum and platinized titanium differ significantly in various papers. It occurs, most likely, because an important role is played not only by the specific surface area of the catalyst, but also by its chemical nature.

In this work, we tried to elucidate the main features of the processes occurring during the electrolysis of low concentrated $(0.15 \mathrm{M}) \mathrm{NaCl}$ solutions depending on the state of the surface of platinized titanium.

\section{Material and methods}

All chemicals were reagent grade. Electrochemical measurements were carried out in $1 \mathrm{M} \mathrm{HClO}_{4}$ with computer controlled MTech PGP-550 M potentiostat (Ukraine) in a standard temperaturecontrolled three-electrode cell. All potentials were recorded and reported vs. $\mathrm{Ag} / \mathrm{AgCl} / \mathrm{KCl}$ (sat.) reference electrode. The reference electrode was brought to the working electrode through the Luggin capillary. The temperature was $25 \pm 1^{\circ} \mathrm{C}$.

Platinized $\mathrm{Ti}$ anode was prepared by deposition of platinum from a nitrite electrolyte on a prepared titanium surface at $10 \mathrm{~mA} \mathrm{~cm}{ }^{-2}$ and $80^{\circ} \mathrm{C}[1,8]$. The surface content of platinum was $2.0 \mathrm{mg} \mathrm{cm}^{-2}$.

The area of anode was $2 \mathrm{~cm}^{2}$ in j, E measurements. The selectivity of the Ti/Pt anode $\left(4 \mathrm{~cm}^{2}\right)$ in the synthesis of sodium hypochlorite was evaluated during the electrolysis of $300 \mathrm{~mL}$ of $0.15 \mathrm{M} \mathrm{NaCl}$ solution in a diaphragm-less cell with a $\mathrm{Ti} / \mathrm{Pt}$ cathode $\left(1 \mathrm{~cm}^{2}\right)$.

The concentration of $\mathrm{NaClO}$ and $\mathrm{NaClO}_{3}$ in solutions was determined by iodometric titration [9]. The standard deviation in determining the concentration does not exceed $\pm 3 \mathrm{mg} \mathrm{L}^{-1}$ and $2 \mathrm{mg} \mathrm{\textrm {L } ^ { - 1 }}$ for sodium hypochlorite and sodium chlorate, respectively. The standard deviations for current efficiencies are \pm 1.0 and $\pm 0.5 \%$ for hypochlorite and chlorate, respectively.

\section{Results and discussion}

The reduction of even utterly oxidized surface of $\mathrm{Ti} / \mathrm{Pt}$ proceeds quite quickly at the potentials of the hydrogen evolution reaction. During the cathodic polarization of the electrode at $-20 \mathrm{~mA} \mathrm{~cm}{ }^{-2}$, the surface is reduced within a few seconds. When pretreated in such a way $\mathrm{Ti} / \mathrm{Pt}$ electrode surface is polarized anodically in the galvanostatic mode, the chronopotentiogram is $\mathrm{S}$-shaped with an induction period during which the potential does not exceed $1.3-1.4 \mathrm{~V}$ in solutions of $0.1-2.0 \mathrm{M} \mathrm{NaCl}$. Let us conventionally call this state of the surface «reduced». After the induction period, one can see a rapid increase in potential to values above $1.6-1.7 \mathrm{~V}$, which corresponds to the «oxidized» surface (Fig. 1). The induction period on a pre-reduced sample in $0.15 \mathrm{M}$ $\mathrm{NaCl}$ is $1000 \mathrm{~s}$ and $160 \mathrm{~s}$ at $20 \mathrm{~mA} \mathrm{~cm}^{-2}$ and $40 \mathrm{~mA}$ $\mathrm{cm}^{-2}$, respectively. In $1.0 \mathrm{M} \mathrm{NaCl}$, the time spent in the reduced state increases significantly and, at given current densities, is 3600 and $1500 \mathrm{~s}$, respectively.

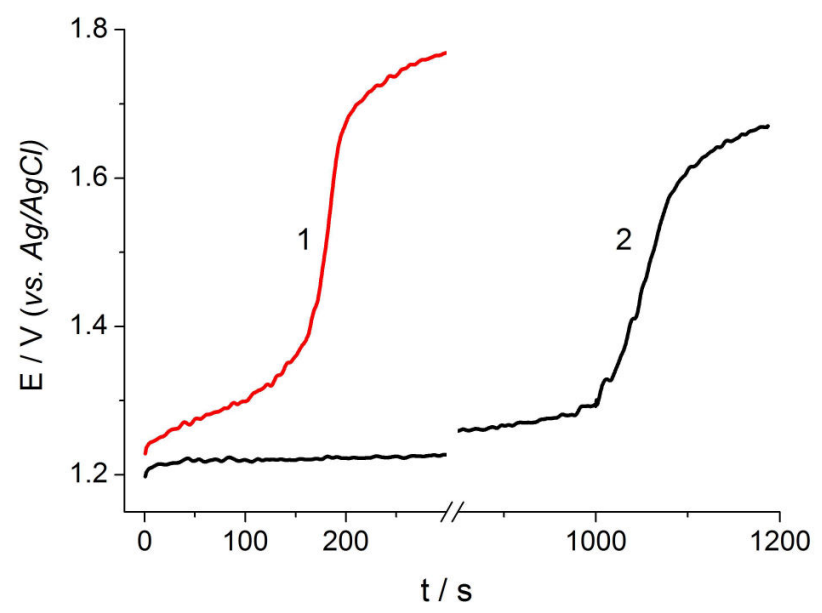

Fig. 1. Chronopotentiograms on pre-treated $\mathrm{Ti} / \mathrm{Pt}$ electrode in $0.15 \mathrm{M} \mathrm{NaCl}$ at $\mathrm{j}_{\mathrm{a}}=40 \mathrm{~mA} \mathrm{~cm}{ }^{-2}$ (1) and $20 \mathrm{~mA} \mathrm{~cm}^{-2}$ (2)

A current wave at the potentials of more positive than $+0.8 \mathrm{~V}$ is observed due to the formation of labile chemisorbed oxygen-containing particles on the reduced platinum surface in $0.15 \mathrm{M} \mathrm{NaCl}$ (Fig. 2, curve 1). When the potential reaches $1.15 \mathrm{~V}$, an exponential increase in current begins, which is because of the discharge of $\mathrm{Cl}^{-}$ions [3]. Further, the current reaches its limiting value of $55-60 \mathrm{~mA} \mathrm{~cm}^{-2}$ (the limiting current wave is not shown in Fig. 1). To get further insight into the processes occurred on the platinum surface during anode polarization, the reduced surface was sequentially polarized at $40 \mathrm{~mA} \mathrm{~cm}{ }^{-2}$ twice during $20 \mathrm{~s}$ and thrice during $60 \mathrm{~s}$. After each polarization cycle, the corresponding polarization curve was recorded (Fig. 2, curves 26). As one can see, curves 2 and 3 are almost parallel to curve 1 , but they are somewhat shifted to more positive potentials, which indicates a gradual oxidation of the surface. The wave of the limiting current corresponding to $\mathrm{Cl}^{-}$discharge is reflected in curve 4 . Curve 5 shows a smaller current, and the current wave in the potential range of $1.2-1.4 \mathrm{~V}$ is 


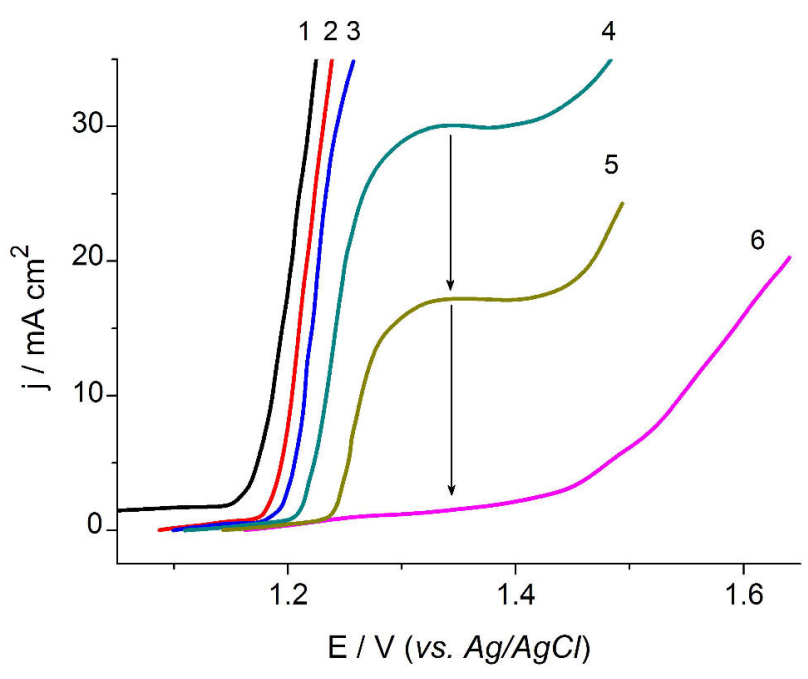

Fig. 2. Voltammograms recorded in $0.15 \mathrm{M} \mathrm{NaCl}$ on the reduced (1) and oxidized (6) surface of Ti/Pt. The numbering of curves is explained in text. $v=20 \mathrm{mV} \mathrm{s}^{-1}$

barely noticeable on the oxidized surface (curve 6). The current wave decreases almost 20 times from 56 to $3 \mathrm{~mA} \mathrm{~cm}{ }^{-2}$ when the state of the electrode surface changes from completely reduced to oxidized. Tafel slopes are $40-50 \mathrm{mV} \mathrm{dec}{ }^{-1}$ and $240 \mathrm{mV} \mathrm{dec}^{-1}$ for curves $1-5$ and curve 6 , respectively. This indicates a significant change in the state of the electrode surface.

One can assume a high integral current efficiency of hypochlorite ions on the reduced surface and sufficiently low integral current efficiency on the oxidized one, since the current on the reduced surface is mainly due to the discharge of chloride ions. Two series of accumulative electrolysis were performed in $0.15 \mathrm{M} \mathrm{NaCl}$ on $\mathrm{Ti} / \mathrm{Pt}$ as an anode at $\mathrm{j}_{\mathrm{a}}=20 \mathrm{~mA} \mathrm{~cm} \mathrm{~cm}^{-2}$ to confirm this assumption. To minimize hypochlorite losses due to its reduction at the cathode, the electrolysis was carried out at $\mathrm{j}_{\mathrm{c}}=-80 \mathrm{~mA} \mathrm{~cm}^{-2}$ and non-intensive mixing [6]. The electrolysis duration was $1000 \mathrm{~s}$, which does not exceed the induction period at a given current density (see Fig. 1). In the first series of experiments, the anode was previously reduced at $j_{c}=-20 \mathrm{~mA} \mathrm{~cm}^{-2}$ during $5 \mathrm{~min}$; in the second series, it was oxidized at $+40 \mathrm{~mA} \mathrm{~cm}{ }^{-2}$ during $20 \mathrm{~min}$. However, contrary to the assumption made, the integrated current efficiency of hypochlorite rises only to $38 \%$ on the reduced surface. Current efficiency of $\mathrm{ClO}^{-}$rises to $29 \%$ on the oxidized surface. The current efficiency of $\mathrm{ClO}_{3}{ }^{-}$on the oxidized surface was $21 \%$, and it was only $9 \%$ on the reduced surface.

We performed steady-state voltammetry measurements to get a further understanding of the electrochemical properties of $\mathrm{Ti} / \mathrm{Pt}$ electrodes during electrolysis of $\mathrm{NaCl}$. For these experiments, a Ti/Pt sample was reduced in $0.15 \mathrm{M} \mathrm{NaCl}$ at $20 \mathrm{~mA} \mathrm{~cm}^{-2}$ during $300 \mathrm{~s}$. Next, the sample was transferred into a cell containing $0.15 \mathrm{M} \mathrm{NaCl}$ and $0.005 \mathrm{M} \mathrm{NaClO}$ (pH 9.0). This solution was obtained by electrolysis of $0.15 \mathrm{M} \mathrm{NaCl}$ solution using $\mathrm{Ti} / \mathrm{Pt}$ electrodes at $\mathrm{j}_{\mathrm{a}}=40 \mathrm{~mA} \mathrm{~cm} \mathrm{~cm}^{-2}$ during $100 \mathrm{~min}$. The use of such a solution minimizes the change in the composition and $\mathrm{pH}$ of the electrolyte during the experiment. The sample was further polarized at $j_{a}=40 \mathrm{~mA} \mathrm{~cm}^{-2}$ for a given period of time $\left(t_{a}\right)$. Then, the electrodes were thoroughly washed in bidistilled water and transferred to a cell containing $1 \mathrm{M} \mathrm{HClO}_{4}$, where the $j, E$ curve was recorded under conditions of linear potential sweep into the cathode region at $\mathrm{v}=10 \mathrm{mV} \mathrm{s}^{-1}$. After recording the $\mathrm{j}$, E curve, the experiment was completely repeated at a new $t_{a}$ value.

As one can see from Fig. 3 (curve 1), a repetitive increase in current is initially observed on the reduced surface, caused by electrochemical adsorption of hydrogen, followed by an increase in current (after $0.0 \mathrm{~V})$, accompanied by hydrogen evolution. After surface oxidation for $5 \mathrm{~s}$, the stationary potential shifts by $30 \mathrm{mV}$ to the anode region, and a current peak appears at the curve with a maximum at $500 \mathrm{mV}$ due to the reduction of labile chemisorbed oxygencontaining particles on the platinum surface. When the sample is oxidized for 10 and $20 \mathrm{~s}$, a further shift of the stationary potential is observed, which indicates continued filling of the surface with chemisorbed oxygen-containing particles. In this case, there is a slight increase in the peak area at $500 \mathrm{mV}$. After oxidation for 40 seconds, a new current wave appears on curve with a maximum at $1.15 \mathrm{~V}$, the area of which increases significantly with increasing anodic polarization time (curves 5-9). The occurrence of this wave even after washing the electrode in bidistilled water (Fig. 4) indicates that the chlorinecontaining particles are firmly fixed to the surface. The reduction wave of $\mathrm{Cl}^{-}$oxidation products practically disappears if the electrode is washed after anodic polarization in an ultrasonic cleaner. This indicates that these particles are fixed on the surface, but their adsorption is reversible. Most likely, these molecules can be $\mathrm{Cl}_{2}$ and $\mathrm{HClO}$ molecules $[4,10]$.

After 100 or more seconds of anodic polarization, a current wave begins to superimpose on the peak of the reduction of chemisorbed oxygencontaining particles at $0.4-0.5 \mathrm{~V}$ due to the reduction of stronger bound chemisorbed oxygen and platinum phase oxides. In this case, the reduction peak area of more labile chemisorbed oxygen-containing particles remains practically unchanged, and the 
surface content of strongly bonded chemisorbed oxygen and phase platinum oxides increases. The assumption that phase oxides begin to form after $100 \mathrm{~s}$ of polarization is in accordance with chronopotentiometric measurements (Fig. 1), which indicate that the reduced surface transforms into an oxidized state in $100-200 \mathrm{~s}$ of polarization at $\mathrm{j}_{\mathrm{a}}=40 \mathrm{~mA} \mathrm{~cm}{ }^{-2}$. A similar increase in the reduction currents of chemisorbed oxygen and phase platinum oxides is seen in cyclic voltammogramms (CV) in $1 \mathrm{M} \mathrm{HClO}_{4}$ at various reversal potentials in the anode region (Fig. 5).

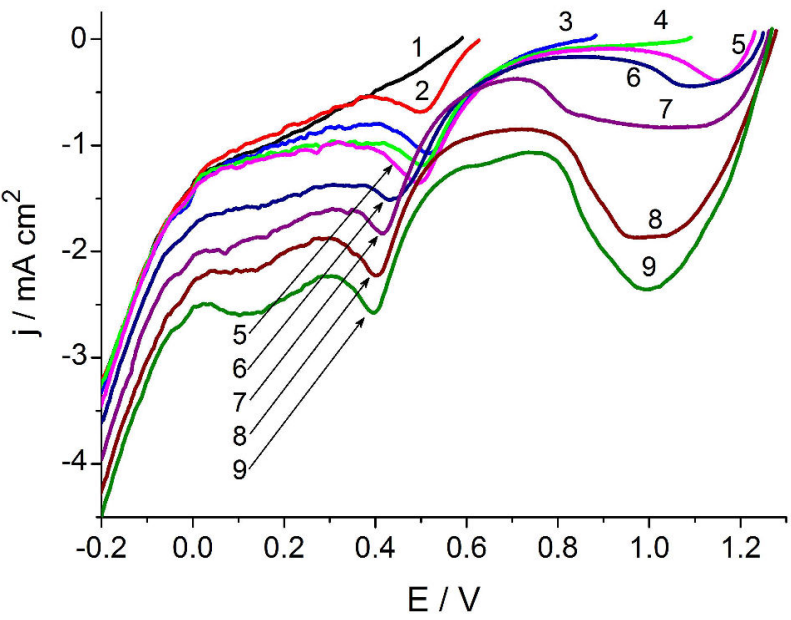

Fig. 3. Voltammetry curves recorded on $\mathrm{Ti} / \mathrm{Pt}$ after anode polarization in $0.15 \mathrm{M} \mathrm{NaCl}+0.005 \mathrm{M} \mathrm{NaClO}$ at $\mathrm{j}_{\mathrm{a}}=40 \mathrm{~mA} \mathrm{~cm}{ }^{-2}$ at different $\mathrm{t}_{\mathrm{a}}$ (s): (1) 0 ; (2) 5 ; (3) 10 ; (4) 20 ;

(5) 40 ; (6) 100 ; (7) 200; (8) 400; (9) 600. Supporting electrolyte $1 \mathrm{M} \mathrm{HClO}_{4} \cdot v=20 \mathrm{mV} \mathrm{s}^{-1}$

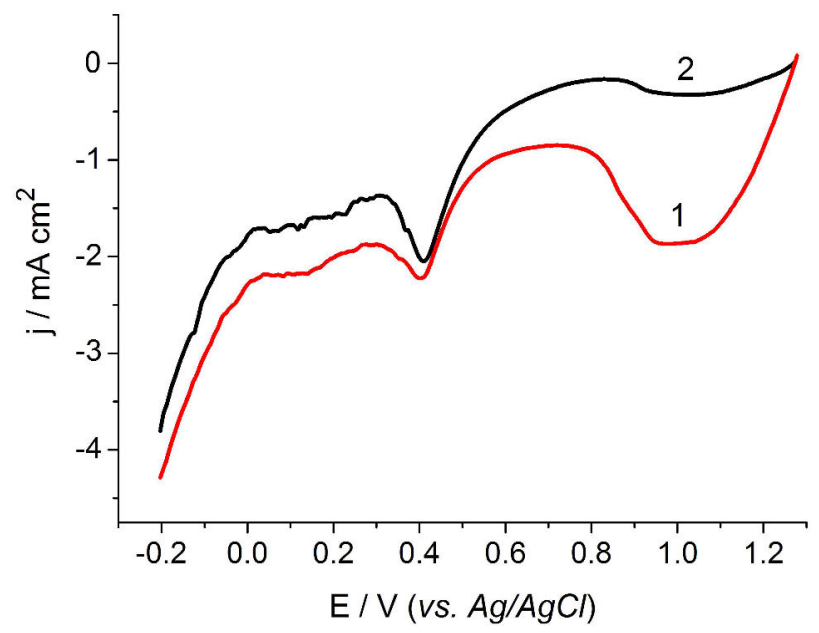

Fig. 4. Voltammetry curves recorded on $\mathrm{Ti} / \mathrm{Pt}$ after anode polarization in $0.15 \mathrm{M} \mathrm{NaCl}+0.005 \mathrm{M} \mathrm{NaClO}$ at

$\mathrm{j}_{\mathrm{a}}=40 \mathrm{~mA} \mathrm{~cm}^{-2}$ during $400 \mathrm{~s}$ (1). The sample was washed in an ultrasonic cleaner after oxidation (2)

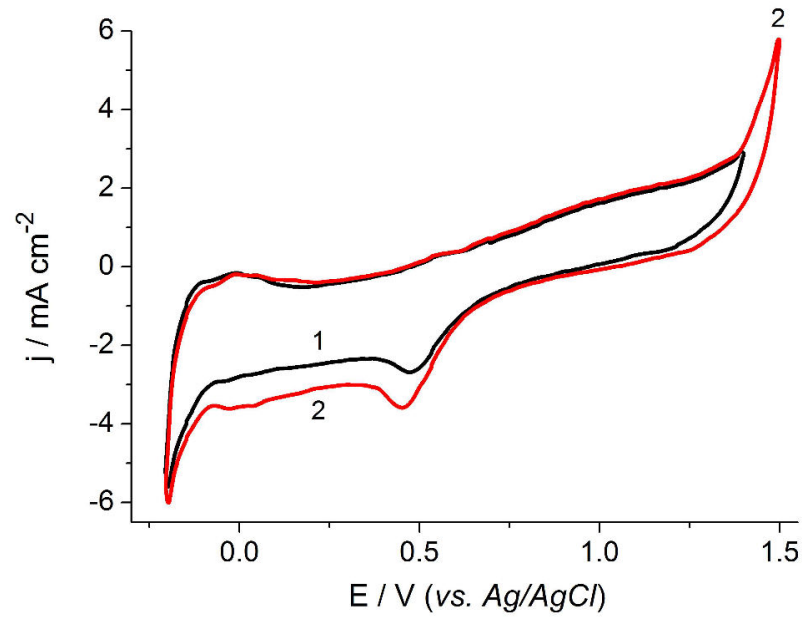

Fig. 5. $\mathrm{CV}$ recorded on $\mathrm{Ti} / \mathrm{Pt}$ in $1 \mathrm{M} \mathrm{HClO}_{4} \cdot \mathrm{v}=50 \mathrm{mV} \mathrm{s}^{-1}$. Potential reverse: $+1.4 \mathrm{~V}$ (curve 1 ) and $+1.5 \mathrm{~V}$ (curve 2 )

One can explain a similar behavior of the surface of platinized titanium by the occurrence of several simultaneous oxygen transfer reactions. The main processes in this case are as follows: (i) oxygen evolution reaction; (ii) chloride ion discharge with the formation of the main $\left(\mathrm{Cl}_{2}, \mathrm{HClO}, \mathrm{ClO}^{-}\right)$and additional $\left(\mathrm{ClO}_{2}^{-}, \mathrm{ClO}_{3}^{-}\right)$products; and (iii) the formation of phase oxides of platinum.

An exponential increase in current at potentials, which are close to the equilibrium potential of chlorine evolution $(1.58 \mathrm{~V})$, on the reduced $\mathrm{Ti} / \mathrm{Pt}$ surface indicates a direct discharge of $\mathrm{Cl}^{-}$(Volmer stage):

$\mathrm{Cl}^{-}=\mathrm{Cl}_{\mathrm{ads}}+\mathrm{e}^{-}$.

Further, recombination (2) or electrochemical desorption (3) occur:

$\mathrm{Cl}_{\mathrm{ads}}+\mathrm{Cl}_{\mathrm{ads}}=\mathrm{Cl}_{2}$

$\mathrm{Cl}_{\mathrm{ads}}+\mathrm{Cl}^{-}=\mathrm{Cl}_{2}+\mathrm{e}^{-}$.

However, even before the $\mathrm{Cl}^{-}$discharge on platinum, the discharge of water and the formation of the first oxide layers from chemisorbed oxygencontaining particles take place [7]:

$$
\begin{aligned}
& \mathrm{H}_{2} \mathrm{O}=\mathrm{OH}_{\mathrm{ads}}+\mathrm{H}^{+}+\mathrm{e}^{-} ; \\
& \mathrm{OH}_{\mathrm{ads}}+\mathrm{H}^{+} \leftrightarrows \mathrm{OH}_{2}{ }^{+} \text {ads } \\
& \mathrm{OH}_{\mathrm{ads}} \leftrightarrows \mathrm{O}^{-}{ }_{\mathrm{ads}}+\mathrm{H}^{+} ; \\
& \mathrm{OH}_{\mathrm{ads}}=\mathrm{O}_{\mathrm{ads}}+\mathrm{H}^{+}+\mathrm{e}^{-} .
\end{aligned}
$$


The pre-reduced surface of the platinized titanium electrode undergoes a series of transformations during the anodic polarization. Oxygen-containing particles $\mathrm{OH}_{\text {ads }}$ are chemisorbed on the $\mathrm{Ti} / \mathrm{Pt}$ surface in the low polarizations range. Such particles, depending on the $\mathrm{pH}$ of the nearelectrode layer, can be in equilibrium with $\mathrm{OH}_{2}{ }^{+}$ads and $\mathrm{O}^{-}$ads $(4, \mathrm{~b}$ and $\mathrm{c})$. With increasing polarization, the formation of atomic oxygen $(4, d)$ and the formation of phase oxide layers become possible $[7,11]$. In stock solutions, the formation of phase surface oxides occurs rapidly, and the oxygen evolution proceeds on a completely oxidized surface. The presence of chloride ions in solution significantly slows down this process. The higher the $\mathrm{Cl}^{-}$ concentration, the longer the surface remains in the reduced state. The chloride ion acts as a depolarizer, discharging on the surface, interacts with surface oxygen-containing particles, thereby slowing down the oxidation of the surface.

Among different mechanisms of chlorine evolution that exist today [12], the features established in this paper can be well described from the point of view of the reaction schemes developed by DentonHarrison:

$$
\begin{aligned}
& \mathrm{Cl}^{-}+\mathrm{S}=\mathrm{S}-\mathrm{Cl}_{\mathrm{ads}}+\mathrm{e}^{-} \\
& \mathrm{H}_{2} \mathrm{O}+\mathrm{S} \leftrightarrows \mathrm{S}-\mathrm{OH}_{\mathrm{ads}}+\mathrm{H}^{+}+\mathrm{e}^{-} ; \\
& \mathrm{S}-\mathrm{Cl}_{\mathrm{ads}}+\mathrm{SOH}_{\mathrm{ads}}=\mathrm{S}-\mathrm{HOCl}_{\mathrm{ads}}
\end{aligned}
$$

and by Erenburg-Krishtalik:

$$
\begin{aligned}
& \mathrm{H}_{2} \mathrm{O}+\mathrm{S} \leftrightarrows \mathrm{S}-\mathrm{OH}_{\mathrm{ads}}+\mathrm{H}^{+}+\mathrm{e}^{-} ; \\
& \mathrm{S}-\mathrm{OH}_{\mathrm{ads}}+\mathrm{Cl}^{-}=\mathrm{S}-(\mathrm{HO}) \mathrm{Cl}_{\mathrm{ads}}+\mathrm{e}^{-} ; \\
& \mathrm{HOCl}+\mathrm{HCl} \leftrightarrows \mathrm{Cl}_{2}+\mathrm{H}_{2} \mathrm{O},
\end{aligned}
$$

where $\mathrm{S}$ is the active surface site.

It should be noted that a direct discharge of $\mathrm{Cl}^{-}$can simultaneously proceed according to the mechanism (1)-(3). For completeness of description, it is appropriate to add to these schemes the stage of desorption of a molecule of hypochlorous acid or chlorine from the surface of the anode, which on the oxidized surface becomes, in all probability, slow:

$$
\mathrm{S}-\mathrm{HOCl}_{\mathrm{ads}} \leftrightarrows \mathrm{S}+\mathrm{HOCl}_{\mathrm{aq}} .
$$

The presence of a slow desorption stage explains the accumulation of $\mathrm{Cl}^{-}$oxidation products on the surface, the reduction peaks of which at potentials of 1.2-0.7 V are observed in Fig. 3.

As shown above, the integrated current efficiency of chlorate is 2 times higher on the oxidized surface than on the reduced one. It is known [13] that chlorate is formed during the electrolysis of chloride-containing solutions through two main routes: (i) electrochemical and (ii) chemical. On an oxidized surface, processes occur at more positive (for $400 \mathrm{mV}$ ) potentials. The shift of the electrode potential during electrolysis to the anode region makes possible the reaction (4d) and, respectively, and leads to an increase in the surface concentration of highly active $\mathrm{O}_{\text {ads }}$ particles. This results in an increase in the rate of further oxidation of $\mathrm{HOCl}_{\mathrm{ads}}$, $\mathrm{HOCl}_{\mathrm{aq}}$ and $\mathrm{ClO}_{\mathrm{aq}}^{-}$to chlorite and chlorate:

$$
\begin{aligned}
& \mathrm{S}-\mathrm{HOCl}_{\mathrm{ads}}+\mathrm{S}-\mathrm{O}_{\mathrm{ads}}=\mathrm{S}-\mathrm{ClO}_{2}^{-}{ }_{\text {ads }}+\mathrm{H}^{+} \\
& \mathrm{S}-\mathrm{O}_{\mathrm{ads}}+\mathrm{ClO}^{-}{ }_{\mathrm{aq}}=\mathrm{S}-\mathrm{ClO}_{2}^{-{ }_{\text {ads }}} \\
& \mathrm{S}-\mathrm{ClO}_{2}{ }^{-}{ }_{\mathrm{ads}}+\mathrm{S}-\mathrm{O}_{\mathrm{ads}}=\mathrm{S}-\mathrm{ClO}_{3}^{-}{ }_{\text {ads }}
\end{aligned}
$$

Equations (8, a-c) describe the electrochemical mechanism of chlorate formation. In the bulk, the concentration of chlorate can also increase due to the following slow reaction:

$$
\mathrm{ClO}^{-}{ }_{\mathrm{aq}}+\mathrm{ClO}_{2}{ }_{\mathrm{aq}} \rightarrow \mathrm{Cl}^{-}{ }_{\mathrm{aq}}+\mathrm{ClO}_{3}^{-}{ }_{\mathrm{aq}} \text {. }
$$

Thus, both the direct electrochemical oxidation of $\mathrm{Cl}^{-}$and its secondary chemical oxidation by labile oxygen-containing particles of the $\mathrm{OH}_{\text {ads }}$ type occur on the reduced $\mathrm{Ti} / \mathrm{Pt}$ surface. The main products are hypochlorous acid and molecular chlorine, which are desorbed from the surface of the electrode and dissolved in the bulk solution. On the oxidized surface, the formation of hypochlorite occurs directly on the surface of the layer of platinum phase oxides with the participation of strongly bonded chemisorbed oxygen-containing particles $\mathrm{OH}_{\text {ads }}$ and atomic oxygen. An increase in the degree of surface filling with more active oxygen-containing particles leads to a significant increase in the rate of formation of chlorate.

\section{Conclusions}

It has been established that the pre-reduced surface of $\mathrm{Ti} / \mathrm{Pt}$ electrode undergoes a series of transformations during the anodic polarization. Layers of labile and then inert chemisorbed oxygencontaining particles begin to form on the $\mathrm{Ti} / \mathrm{Pt}$ surface in the region of low polarizations. With increasing polarization, the formation of atomic oxygen becomes possible and phase oxide layers are formed. In stock solutions, the formation of phase 
surface oxides occurs rapidly, and the oxygen evolution proceeds on a completely oxidized surface. The presence of $\mathrm{Cl}^{-}$in solution significantly decelerates this process. Chloride ion acts as a depolarizer, discharging, interacts with surface oxygen-containing particles, thereby slowing down the oxidation of the surface. Thus, both direct oxidation of $\mathrm{Cl}^{-}$and its oxidation by labile oxygencontaining particles of the $\mathrm{OH}_{\text {ads }}$ type occur on the reduced platinized surface. On the oxidized surface, the formation of hypochlorite occurs directly on the surface of the layer of platinum phase oxides with the participation of strongly bounded (inert) chemisorbed oxygen-containing particles and atomic oxygen. The desorption of the products of primary oxidation of $\mathrm{Cl}^{-}$becomes slower, and an increase in the degree of surface filling with active oxygencontaining particles of the $\mathrm{O}_{\text {ads }}$ type leads to a significant increase in the rate of chlorate formation.

\section{REFERENCES}

1. Kasian O., Luk'yanenko T., Velichenko A. Oxidation of $\mathrm{Cr}^{3+}$-ions at the composite $\mathrm{TiO}_{\mathrm{x}} / \mathrm{PtO}_{\mathrm{y}}$ electrode // ECS Trans. 2013. - Vol.45(9). - P.13-18.

2. Kodera F., Umeda M., Yamada A. Effect of platinum oxide on electro-oxidation of trace amounts of sodium hypochlorite in aqueous medium // J. Electroanal. Chem. 2009. - Vol.625. - P.92-96.

3. Girenko D.V., Velichenko A.B. Synthesis of low concentration solutions of sodium hypochlorite in an electrolyzer with undivided electrode space // Voprosy Khimii i Khimicheskoi Tekhnologii. - 2013. - No. 4. - P.82-91.

4. On the electrolysis of dilute chloride solutions: influence of the electrode material on Faradaic efficiency for active chlorine, chlorate and perchlorate / Neodo S., Rosestolato D., Ferro S., De Battisti A. // Electrochim. Acta. - 2012. - Vol.80. - P.282291.

5. Czarnetzki L., Janssen L.J.J. Electrochemical oxidation of hypochlorite at platinum anodes // Electrochim. Acta. - 1988. - Vol.33. - P.561-566.

6. Girenko D.V., Velichenko A.B. Selection of the optimal cathode material to synthesize medical sodium hypochlorite solutions in a membraneless electrolyzer // Surf. Eng. Appl. Electrochem. - 2018. - Vol.54. - P.88-95.

7. Trasatti $S$. Electrocatalysis: understanding the success of DSA® // Electrochim. Acta. - 2000. - Vol.45. - P.23772385 .

8. Electrodeposition of $\mathrm{Ni}^{2+}$-doped $\mathrm{PbO}_{2}$ and physicochemical properties of the coating / Shmychkova O., Luk'yanenko T., Amadelli R., Velichenko A. // J. Electroanal. Chem. - 2016. - Vol.774. - P.88-94.
9. Girenko D.V., Gyrenko A.A., Nikolenko N.V. Potentiometric determination of chlorate impurities in hypochlorite solutions // Int. J. Anal. Chem. - 2019. - Vol.2019. - Article No. 2360420.

11. The study of the electrooxidation of chloride at $\mathrm{RuO}_{2} / \mathrm{TiO}_{2}$ electrode using $\mathrm{CV}$ and radiotracer techniques and evaluating by electrochemical kinetic simulation methods / Tomcsanyi L., De Battisti A., Hirschberg G., Varga K., Liszi J. // Electrochim. Acta. - 1999. - Vol.44. - P.2463-2472.

12. Electrochemical chlorine evolution at rutile oxide (110) surfaces / Hansen H.A., Man I.C., Studt F., Abid-Pedersen F., Bligaard T., Rossmeisl J. // Phys. Chem. Chem. Phys. - 2010. Vol.12. - P.283-290.

13. A review of chlorine evolution mechanism on dimensionally stable anode $\left(\mathrm{DSA}^{\circledR}\right)$ / Kim J., Kim C., Kim S., Yoon J. // Korean Chem. Eng. Res. - 2015. - Vol.53. - P.531539.

Received 10.10.2019

\section{ВПЛИВ ПОПЕРЕДНЬОГО ОБРОБЛЕННЯ Тi/Pt ЕЛЕКТРОДІВ НА ЇХ ЕЛЕКТРОХІМІЧНІ ВЛАСТИВОСТІ ПРИ ЕЛЕКТРОЛІЗІ $\mathrm{NaCl}$}

\section{Д. Гиренко, О. Шмичкова, О. Веліченко}

Показано, що попередньо відновлена поверхня платинованого титанового електрода зазнає низки перетворень під час анодної поляризації. За низьких поляризацій на поверхні Tі/ Pt хемосорбуються оксигеновмісні частинки $\mathrm{OH}_{\text {ads. }}$ Такі частинки, залежно від рН навколоелектродного шару, можуть перебувати в рівновазі з $\mathrm{OH}_{2}^{+}{ }_{\text {ads }}$ ma $\mathrm{O}^{-}{ }_{\text {ads. }}$. Зі збільшенням поляризації можливе утворення атомарного оксигену та утворення фазових шарів оксиду. У фонових розчинах утворення фазових поверхневих оксидів відбувається швидко, і виділення кисню відбувається на повністю окисленій поверхні. Наявність іонів хлориду в розчині значно сповільнюе ией процес. Чим вища концентрація $\mathrm{Cl}^{-}$, тим довше поверхня залишається відновленою. Хлорид-іон діє як деполяризатор, розряджаючись на поверхні, взаємодіє з поверхневими оксигеновмісними частинками, тим самим сповільнюючи окислення поверхні. Встановлено, що як пряме окислення $\mathrm{Cl}^{-}$, так і його окислення лабільними оксигеновмісними частинками типу $\mathrm{OH}_{\text {ads }}$ відбуваються на відновленій платинованій поверхні. На окисленій поверхні утворення гіпохлориту відбувається безпосередньо на поверхні шару фазових оксидів платини за участю інертних хемосорбованих оксигеновмісних частинок та атомарного оксигену. Десорбція продуктів первинного окислення $\mathrm{Cl}^{-}$сповільнюється, а збільшення ступеня поверхневого наповнення активними оксигеновмісними частинками типу $O_{a d s}$ приводить до значного збільшення швидкості утворення хлоратів.

Ключові слова: платинований титан, електрод, попереднє оброблення, натрій гіпохлорит, електроліз. 


\section{INFLUENCE OF Ti/Pt ELECTRODES HISTORY ON ITS ELECTROCHEMICAL PROPERTIES DURING ELECTROLYSIS OF NaCl}

\section{Girenko, O. Shmychkova, A. Velichenko *}

Ukrainian State University of Chemical Technology, Dnipro, Ukraine

* e-mail: velichenko@ukr.net

It was shown that the pre-reduced surface of the platinized titanium electrode undergoes a series of transformations during the anodic polarization. Oxygen-containing particles $\mathrm{OH}_{\text {ads }}$ are chemisorbed on the Ti/Pt surface in the low polarizations range. Such particles, depending on the $\mathrm{pH}$ of the near-electrode layer, can be in equilibrium with $\mathrm{OH}_{2}^{+}{ }_{\text {ads }}$ and $\mathrm{O}^{-}{ }_{\text {ads }}$. With increasing polarization, the formation of both atomic oxygen and phase oxide layers becomes possible. The formation of phase surface oxides occurs rapidly in supporting electrolytes, and the oxygen evolution proceeds on a completely oxidized surface. The presence of chloride ions in solution significantly decelerates this process. The higher the $\mathrm{Cl}^{-}$ concentration, the longer the surface remains in the reduced state. The chloride ion acts as a depolarizer, discharging on the surface and interacting with surface oxygen-containing particles, thereby slowing down the oxidation of the surface. It was established that both direct oxidation of $\mathrm{Cl}^{-}$and its oxidation by labile oxygencontaining particles of the $\mathrm{OH}_{\text {ads }}$ type occur on the reduced platinized surface. On the oxidized surface, the formation of hypochlorite occurs directly on the surface of the layer of platinum phase oxides with the participation of inert chemisorbed oxygen-containing particles and atomic oxygen. The desorption of the products of primary oxidation of $\mathrm{Cl}^{-}$becomes slower, and an increase in the degree of surface filling with active oxygen-containing particles of the $O_{\text {ads }}$ type leads to a significant increase in the rate of chlorate formation.

Keywords: platinized titanium; electrode; pre-treatment; sodium hypochlorite; electrolysis.

\section{REFERENCES}

1. Kasian O., Luk'yanenko T., Velichenko A. Oxidation of $\mathrm{Cr}^{3+}$-ions at the composite $\mathrm{TiO}_{\mathrm{x}} / \mathrm{PtO}_{\mathrm{y}}$ electrode. ECS Transactions, 2013, vol. 45, pp. 13-18.

2. Kodera F., Umeda M., Yamada A. Effect of platinum oxide on electro-oxidation of trace amounts of sodium hypochlorite in aqueous medium. Journal of Electroanalytical Chemistry, 2009, vol. 625, pp. 92-96.

3. Girenko D.V., Velichenko A.B. Sintez nizkokontsentrirovannykh rastvorov gipokhlorita natriya $\mathrm{v}$ elektrolizerakh bez razdeleniya mezhelektrodnogo prostranstva [Synthesis of low concentration solutions of sodium hypochlorite in an electrolyzer with undivided electrode space]. Voprosy Khimii i Khimicheskoi Tekhnologii, 2018, no. 4, pp. 82-91. (in Russian).
4. Neodo S., Rosestolato D., Ferro S., De Battisti A. On the electrolysis of dilute chloride solutions: influence of the electrode material on Faradaic efficiency for active chlorine, chlorate and perchlorate. Electrochimica Acta, 2012, vol. 80, pp. 282-291.

5. Czarnetzki L., Janssen L.J.J. Electrochemical oxidation of hypochlorite at platinum anodes. Electrochimica Acta, 1988, vol. 33, pp. 561-566.

6. Girenko D.V., Velichenko A.B. Selection of the optimal cathode material to synthesize medical sodium hypochlorite solutions in a membraneless electrolyzer. Surface Engineering and Applied Electrochemistry, 2018, vol. 54, pp. 88-95.

7. Trasatti S. Electrocatalysis: understanding the success of DSA ${ }^{\circledR}$. Electrochimica Acta, 2000, vol. 45, pp. 2377-2385.

8. Shmychkova O., Luk'yanenko T., Amadelli R., Velichenko A. Electrodeposition of $\mathrm{Ni}^{2+}$-doped $\mathrm{PbO}_{2}$ and physicochemical properties of the coating. Journal of Electroanalytical Chemistry, 2016, vol. 774, pp. 88-94.

9. Girenko D.V., Gyrenko A.A., Nikolenko N.V. Potentiometric determination of chlorate impurities in hypochlorite solutions. International Journal of Analytical Chemistry, 2019, vol. 2019, article no. 2360420.

11. Tomcsanyi L., De Battisti A., Hirschberg G., Varga K., Liszi J. The study of the electrooxidation of chloride at $\mathrm{RuO}_{2} / \mathrm{TiO}_{2}$ electrode using $\mathrm{CV}$ and radiotracer techniques and evaluating by electrochemical kinetic simulation methods. Electrochimica Acta, 1999, vol. 44, pp. 2463-2472.

12. Hansen H.A., Man I.C., Studt F., Abid-Pedersen F., Bligaard T., Rossmeisl J. Electrochemical chlorine evolution at rutile oxide (110) surfaces. Physical Chemistry Chemical Physics, 2010, vol. 12, pp. 283-290.

13. Kim J., Kim C., Kim S., Yoon J. A review of chlorine evolution mechanism on dimensionally stable anode (DSA $\left.{ }^{\circledast}\right)$. Korean Chemical Engineering Research, 2015, vol. 53, pp. 531539. 